\title{
Obituaries
}

\section{Judd Marmor}

Psychiatrist who changed the view of homosexuality as a mental disorder

When Judd Marmor's patients didn't fit the textbook theory that homosexuality was an illness, he thought perhaps the theory was wrong.

In 1973, as a prominent and heterosexual psychiatrist, he became a leader in the struggle that led to the removal of the definition of homosexuality as an illness from the American Psychiatric Association's Diagnostic and Statistical Manual of Mental Disorders, changing a position it had held for nearly a century. The following year he was elected president of the association, one of many posts he held during a long career.

Dr Marcia Goin, clinical professor of psychiatry at Keck School of Medicine at the University of Southern California and current president of the American Psychiatric Association, was a student, colleague, and friend of Marmor. She recalls, "What was really, really important with Judd was his openness to new things. Freud was very open; he listened to patients and if it didn't fit, he dismissed the theory. Judd kept his mind open to his 93rd year." She said, "He was a key figure in depathologising homosexuality. It grew out of his experience listening to patients."

The playwright Arthur Laurents, author of West Side Story, was one of the gay men who consulted Dr Marmor, according to the online newspaper Gay Today, which reported the following tale from The Gay Metropolis: 1940-1996 by Charles Kaiser. Laurents remembered that Marmor had greeted him with the usual question, "Why are you here?" "I'm afraid I'm homosexual," Laurents replied. "So?" "What do you mean, 'So?' You know it's dirty and disgusting," said Laurents. "I don't know anything about it," said Marmor. Then Marmor is reported to have said something that would change Laurents's life forever: "All I know is that whoever or whatever you are, if you lead your life with pride and dignity, that's all that matters."

Dr Robert Galatzer-Levy, lecturer at the University of Chicago and co-author of The Course of Gay and Lesbian Lives, said, "Marmor was a political liberal interested in civil rights. He was absolutely aware of the use of psychiatry to oppress people-in the US and Britain and of course in Russia." He

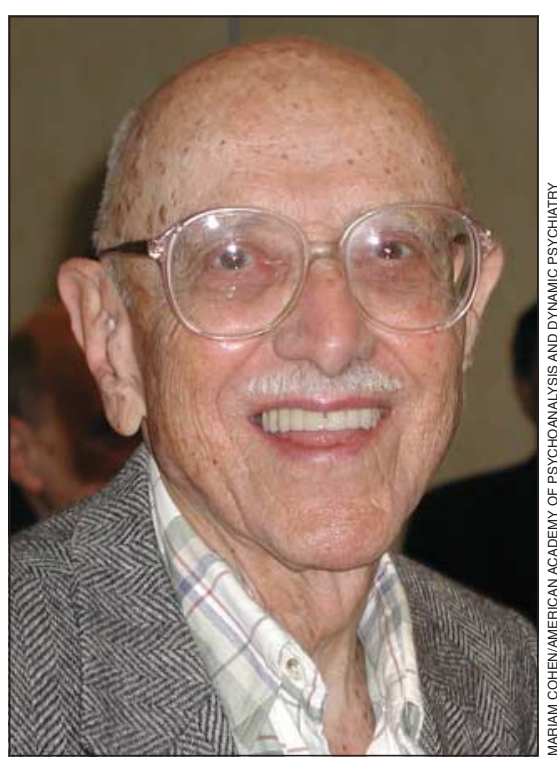

ily moved to the United States and he grew up in Chicago and later in New York. After graduating in medicine at Columbia University's College of Physicians and Surgeons while supporting himself with odd jobs and debating scholarships, he set up a psychiatric practice in New York. During the second world war he served in the US navy. After the war he moved to Los Angeles, where he became a psychoanalyst to Hollywood celebrities.

He began to treat homosexual patients who wanted to change their sexual orientation, as then recommended. He wasn't too successful. According to Eric Marcus's Making History: The Struggle for Gay and Lesbian Equal Rights 1945-1990 Marmor was appalled by psychiatrists' generalisations about homosexuals: "All terribly nasty, negative, disparaging things. I knew gay men and women. This view just didn't make sense to me."

Marmor was director of the division of psychiatry at Cedars-Sinai Medical Center, professor of psychiatry at the University of Southern California Keck School of Medicine, and adjunct professor of psychiatry at the UCLA David Geffen School of Medicine, all in Los Angeles. He served as president of the American Psychiatric Association, the Group for Advancement of Psychiatry, and the American Academy of Psychoanalysis. He published eight books and more than 350 scientific papers. $\mathrm{He}$ reached millions of ordinary Americans as informal consultant to the syndicated "Dear Abby" newspaper advice column.

He loved tennis and played three times a week into his early 90s. With his wife, Dr Katherine Marmor, he began collecting American art in the 1950s, including works by Roy Lichtenstein, Frank Stella, Andy Warhol, and Jasper Johns. Prints from the collection were exhibited at the Stanford University Museum of Art in 1997.

Predeceased by Katherine, he leaves a son and two grandchildren. [JANICE Hopkins TANNE]

Judd Marmor, professor of psychiatry University of Southern California (b London 1910; $q$ Columbia University College of Physicians and Surgeons, New York, 1933), died from congestive heart failure on 16 December 2003. 


\section{Thomas David Meurig Adams}

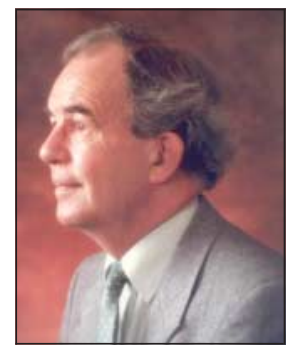

Former general practitioner Portland, Dorset (b 1928; q Liverpool 1951), d 12 January 2004.

In 1968 he was involved in setting up what was to become the Portland Group Practice, which served 11000 patients on the island of Portland and provided locum cover for the Verne prison and the young offender institution. David was also an admiralty surgeon and agent working with naval personnel. Predeceased by his first wife, Hilary, he leaves his second wife, Rosemary; three daughters; and one stepdaughter. A memorial service will take place at $1130 \mathrm{am}$ on 27 February 2004 at St John's Church, Fortuneswell, Portland, Dorset. For further details telephone 0207020 7862. [DAvID B HaRgRaVE]

\section{James Taylour Doyle Allen}

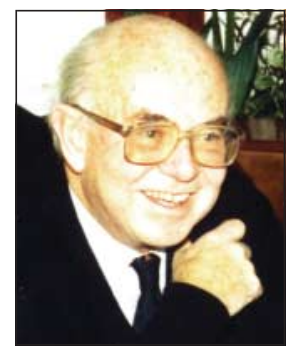

Former general practitioner Crosby, Liverpool (b Liverpool 1922; q Liverpool 1944), died from metastatic renal cancer on 18 December 2003.

After qualifying Jim was immediately drafted into the army, serving in South East Asia. He worked in Liverpool Royal Infirmary before setting up practice in the Crosby and Waterloo area of Liverpool, where he remained a principal until retirement in 1988. He was also a part time hospital practitioner in allergy at the Royal Infirmary and Alder Hey Children's Hospital. Jim had a lifelong passion for sailing. He leaves a wife, Ruth; two children; and four grandchildren. [Dorothy MAGENNIS, DAVID MELdRUM]

\section{Francis Exton Crawley}

Former consultant chest physician Liverpool (b Walney Island 1911; q Glasgow 1933; DPH, MD, FRCP), died from a stroke on 20 December 2003.

In 1947 he began his career as a consultant chest physician in Dorset. In 1950 he moved to Liverpool to begin his dream job as chief of a purpose built chest clinic, which he also administered. He was called the "flying doctor" because he ran round the hospital and clinic taking the stairs two at a time, leaving his staff puffing along behind him. In 1976 he retired to Ayr, where he indulged his love of horse racing as occasional race course doctor. Predeceased by his wife, Evalyn, he leaves three children and seven grandchildren. [Evalyn MacLEOD]

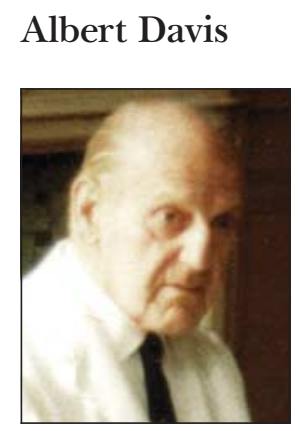

Former consultant obstetrician London (b Manchester 1904; q Manchester 1925; MD, FRCS, FRCOG), d 21 October 2003.

$\mathrm{He}$ was the father of neuro-gynaecology and his lifelong concern was with chronic pelvic pain, which he treated with either alcohol injection or open presacral neurectomy. He was turned down for war service in the army, being obstetrician already to the south east London metropolitan sector and ordered to add to his duties as the sole obstetrician in the north east sector. Here he honed his surgical skills, and his record on caesarean sections was 11 procedures in a day. He developed the largest practice in the United Kingdom with 100 gynaecological and 25 obstetric beds. In 1950 he brought to the public's attention the horrors of backstreet abortion (BMJ 15 July 1950). He leaves a wife, Renate; two children; and his grandchildren. [CHARLES DAvIS]

\section{Ian Cunningham Sinclair Knight}

Former professor of urological surgery University of New Mexico Medical School, Albuquerque, New Mexico, United States (b 1923; q Edinburgh 1946; FRCS Ed), died from heart failure on 6 December 2003.

Ian served for three years in the Royal Air Force, returning to Edinburgh to complete his general surgical training. He became a consultant urologist in Doncaster, but in 1966 , as he was plagued by respiratory problems, he decided to emigrate to New Mexico, with its pollution free dry climate. Following his tenure as professor of urology at the University of New Mexico Medical School, he was in private practice for 30 years. He leaves a wife, Ethel; three children; and two grandsons. [DonALD C MacPhail]

\section{Peter Davison Knights}

General practitioner Norwich (b China 1940; $q$ Middlesex Hospital 1964;DRCOG), died

from a cerebral glioma on 10 November 2003.

Peter's parents ran a leper hospital in China during invasion and civil war and were evacuated with 5 year old Peter on the last plane out. He rarely spoke of what he saw at that time, but it undoubtedly informed his approach to medicine and to life. After retirement and voluntary service in Cameroon, he did as much locum work as he could find time for. His chief love outside medicine was sailing, at which he competed nationally. $\mathrm{He}$ leaves a wife, Sue; three children; and two grandchildren. [B S CoLE]

\section{John Mackenzie Matheson}

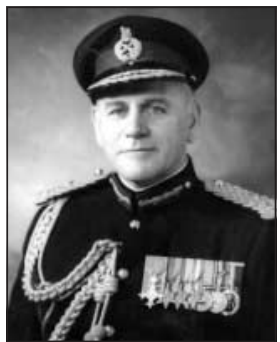

Former professor of military surgery Royal Army Medical College (b Gibraltar 1912; q Edinburgh 1936; FRCP Ed, OBE, TD), d 9 November 2003. John Mackenzie Matheson saw service during the second world war in Palestine, the Middle East, Italy, and north Africa, where he was largely responsible for the organisation of the medical services for the Tunisian campaign in the Western Desert, before and after El Alamein, for which he was mentioned in dispatches. After the war he remained in the Royal Army Medical Corps and over the next 36 years served as a surgical consultant in many parts of the world, including the United States, Egypt, Singapore, Hong Kong, and Nepal. His final post in the army, in the rank of major-general, was as commandant of the Army Medical College at Millbank, professor of military surgery, and honorary surgeon to the Queen. In 1971 he was appointed postgraduate dean of medicine at Edinburgh University. Predeceased by his wife, Nan, he leaves a daughter. [MARGARET Williams]

\section{Graham Thomas}

Former consultant pathologist London (b 1916; $q$ Cambridge/Guy's Hospital, London, 1942; FRCPath), d 8 December 2003.

During the second world war he served in Burma with the Royal Army Medical Corps. He specialised in pathology and became a consultant for several years at the Millar and St Alfege's hospitals in London and, when they closed, at Greenwich District Hospital, retiring in 1981. He leaves a wife, Billie, and three sons. [C J Thomas]

Longer versions of these obituaries are available on bmj.com 